\title{
Theophylline and Leukotriene Modifiers: Is There Any Compelling Role in COPD?
}

\author{
Abhijeet Singh, Rajendra Prasad ${ }^{1}$, Nikhil Gupta ${ }^{2}$ \\ Department of Pulmonary and Critical Care Medicine, Medeor JCS Institute of Pulmonary, Critical Care and Sleep Medicine, New Delhi, ${ }^{1}$ Department of Pulmonary Medicine, \\ Era's Lucknow Medical College and Hospital, ${ }^{2}$ Department of General Medicine, Dr. Ram Manohar Lohia Institute of Medical Sciences, Lucknow, Uttar Pradesh, India
}

\section{Abstract}

Chronic obstructive pulmonary disease (COPD) is considered to be an emerging global public health problem. Inhaled therapies are first-line maintenance treatment for COPD, whereas oral drug therapies are used as second or third line maintenance treatment. Oral drugs have modest bronchodilatory as well as anti-inflammatory activities but have lower potency as compared to inhaled therapies. Oral drug therapy can play an important role with several advantages that include distinctive pharmacologic mechanisms of action, prompt availability, ease of administration without the challenges of proper inhalational drug deposition in airways of lung and cost-effectiveness. Theophyllines and leukotriene modifiers are frequently prescribed oral drug therapies worldwide. Although evidence remains weak regarding the exact role of theophyllines in COPD, they are still used alone or as an add-on agent to inhaled therapies but at the expense of narrow therapeutic index leading to dose-dependent toxicities. Leukotriene modifiers are currently prescribed as add-on agents to inhaled therapies in moderate-to-severe asthma. However, the role of leukotriene modifiers in COPD is not very convincing with limited evidence. Overall, there is not any compelling evidence on the utility of theophyllines and leukotriene modifiers in the management of COPD.

Keywords: Chronic obstructive pulmonary disease, leukotriene modifiers, montelukast, theophylline

\section{INTRODUCTION}

Chronic obstructive pulmonary disease (COPD) is a chronic airway disorder characterized by persistent symptoms and airflow limitation with a lack of significant bronchodilator reversibility in majority of cases as evident on spirometry when performed under appropriate conditions ${ }^{[1]}$ COPD is considered to be an emerging public health problem with an estimated global prevalence of $11.7 \% .{ }^{[2]}$ It has been currently ranked fourth among leading causes of mortality worldwide but is projected to be the third leading cause in subsequent years. ${ }^{[3]}$ More than 3 million deaths occurred ever year due to COPD accounting for $6 \%$ of all global deaths. ${ }^{[4]}$ The disease is associated with significant morbidity and mortality carrying substantial and expanding socioeconomic burden worldwide. ${ }^{[5]}$ The burden of COPD is increasing even in developing countries like India, although the magnitude of burden of disease is not exactly defined. The prevalence of COPD in India is estimated to be $3.67 \%$ with annual mortality rate of $500,000 .^{[6,7]}$

The use of drug therapy in COPD has expanded over the past several decades with a better outcome. Inhaled therapies play

\begin{tabular}{|l|l|}
\hline \multicolumn{2}{|c|}{ Access this article online } \\
\hline Quick Response Code: & Website: \\
\hline & www.ijrconline.org \\
\cline { 2 - 2 } & \\
\hline
\end{tabular}

a pivotal role as these are typically preferred for the first-line maintenance treatment of COPD. ${ }^{[1,8]}$ The advantages of inhaled therapies include direct delivery of medications into the airways leading to improvement in efficacy, rapid onset of action, and lesser risk for systemic adverse effects. ${ }^{[8]}$ Oral drug therapies are used for second or third line maintenance treatment of COPD. The most commonly used oral drugs are theophylline, leukotriene modifiers, macrolides, phosphodiesterase (PDE) inhibitors, and mucolytic agents. Oral drugs can play an important role as advantages include distinctive pharmacologic mechanisms of action, ease of administration, without the challenges of proper inhalational drug deposition in airways of lung and relatively cheaper than inhaled therapies. ${ }^{[8]}$ These

\section{Address for correspondence: Prof. Rajendra Prasad, \\ Era's Lucknow Medical College and Hospital, Lucknow - 226 003, Uttar Pradesh, India.} E-mail: rprasaddirvpci@gmail.com

This is an open access journal, and articles are distributed under the terms of the Creative Commons Attribution-NonCommercial-ShareAlike 4.0 License, which allows others to remix, tweak, and build upon the work non-commercially, as long as appropriate credit is given and the new creations are licensed under the identical terms.

For reprints contact: reprints@medknow.com

How to cite this article: Singh A, Prasad R, Gupta N. Theophylline and leukotriene modifiers: Is there any compelling role in COPD? Indian $\mathrm{J}$ Respir Care 2020;9:153-61.

Received: $15-12-2019$

Accepted: 25-02-2020

Revised: 29-01-2020 Published: 05-06-2020 
agents have anti-inflammatory or immunomodulatory effects as the predominant pharmacologic mechanism of action for clinical benefit. Other mechanisms include reduction of exacerbations and fairly rapid bronchodilation but less than that achieved with inhaled therapies. There is uncertainty regarding the role of theophylline and leukotriene modifiers either used alone or in combination in patients having COPD. This review highlights the current evidence regarding the role of theophylline and leukotriene modifiers in COPD.

\section{Search Strategy}

Published studies related to role of theophylline and leukotriene modifiers in COPD were searched involving principal electronic databases (PUBMED, National Library of Medicine, EMBASE, Web of Science, Index Copernicus, Google scholar, and IndMed) from 1950 till now, using the index terms (Medical Subject Headings) in combination: "Chronic Obstructive Pulmonary Disease" or "COPD," and "Theophyllines" or "Methylxanthines" or "Xanthine derivatives" and "Leukotriene modifiers" or "Leukotriene receptor antagonists" or "Montelukast" or "Zileuton." Other terms such as "Oral drug therapies" and "Obstructive lung diseases" were also used. A manual search was also performed in addition. Twenty-five articles including three systematic reviews have been identified. All articles with resulting titles and abstracts were screened. The full text of relevant articles was read and kept for reference.

\section{Role of Theophyllines in Chronic Obstructive Pulmonary Disease}

Theophylline is a drug extracted from a purine derivative (1, 3-dimethyl xanthine) and is naturally present in tea, cocoa, and beans. It was one of the drugs earlier used for the treatment of asthma, initially as aminophylline both in oral and intravenous forms. This drug had a very narrow therapeutic window as doses used at that time for bronchodilation, were also associated with severe gastrointestinal, cardiac, and central nervous system (CNS) adverse effects. Seizures, cardiac arrhythmias, and even mortality were also observed when blood concentrations became too high due to pharmacokinetic interactions. Subsequently, theophylline gained popularity with the availability of sustained release products and commercial automated assays that allowed convenient blood level monitoring. However, the utility of theophylline declined when inhaled bronchodilators were introduced since the past few decades.

Theophylline is usually prescribed at lower concentrations based on its anti-inflammatory effects in COPD and is a safer option currently than in the past. It usually acts as smooth muscle relaxant located in the bronchial airways and pulmonary blood vessels. ${ }^{[9]}$ It also reduces the airway responsiveness to various agents such as histamine, adenosine, methacholine, and allergens. There are two major pharmacological mechanisms of action for theophylline which include broad spectrum
PDE inhibition leading to increase in the concentration of intracellular cyclic adenosine monophosphate and guanosine monophosphate, activation of protein kinase A, inhibition of tumor necrosis factor alpha and leukotriene synthesis and another adenosine receptor antagonist leading to anti-inflammatory effects. ${ }^{[8,9]}$

Other proposed mechanisms of action showing anti-inflammatory effects include inhibition of nuclear factor-kappa B leading to reduction of the expression of known inflammatory genes in COPD, enhancement of interleukin-10 secretion, increasing histone deacetylase 2 (HDAC 2) activity, inhibiting phosphoinositide 3-kinase-delta, decreasing poly (ADP-ribose) polymerase-1, and promotion of apoptosis of inflammatory cells such as T cells and neutrophils. ${ }^{[9,10]}$ All these actions occur at a higher therapeutic dosage ranging from 10 to $20 \mathrm{mcg} / \mathrm{ml}$, whereas the effect on HDAC 2 is observed at a lower dosage ranging from 5 to $10 \mathrm{mcg} / \mathrm{ml}$. Apart from anti-inflammatory effects, theophylline also exhibits mild bronchodilation (increase forced expiratory volume in $1 \mathrm{~s}$ [FEV1], decreased air-trapping, and improvement in gas exchange), decrease in work of breathing by improving diaphragm contractility, respiratory stimulation, promotion of mucociliary clearance, and suppression of cough. ${ }^{[1]}$

Desired therapeutic concentrations of theophylline for children and adults are $5-15 \mathrm{mcg} / \mathrm{ml}$ and $10-20 \mathrm{mcg} / \mathrm{ml}$, respectively, whereas toxicity is increased when concentration exceeds $20 \mathrm{mcg} / \mathrm{ml} .^{[12]}$ There are interactions with several drugs such as cimetidine, ciprofloxacin, erythromycin, clarithromycin, and rifampicin due to alterations in hepatic metabolism primarily with not only the CYP1A2 but also the CYP3A4 metabolizing enzymes. Therapeutic dose monitoring is required in various conditions such as congestive cardiac failure, liver disorders, viral infections, morbid obesity, atrial fibrillation, and smoking. Low doses of theophylline such as $100-200 \mathrm{mg}$ twice daily as a sustained release with target blood levels of 5-10 mcg/ $\mathrm{mL}$ is currently recommended considering the risk-benefit ratio. It is best to titrate the dose upward on initiation with monitoring of drug levels in blood as indicated for suspicion of toxicity. Dose-dependent toxicity is observed such as gastrointestinal (nausea, vomiting, and discomfort) and CNS (headache, sleeplessness, and seizures). ${ }^{[13]}$ Gastrointestinal side-effects and diuresis have been observed due to PDE inhibition, whereas cardiac arrhythmias and seizures are due to adenosine receptor antagonism that occurs at very high plasma concentrations.

Newer derivatives, such as doxofylline $(1,3$ dioxolane-2-yl methyl) and acebrophylline (ambroxol + theophylline-7-acetate) with decreased affinity for adenosine receptors, have been showing similar efficacy but have better cardiovascular and CNS toxicity profile as compared to theophyllines. A network meta-analysis has observed doxofylline to be the best xanthine in the treatment of COPD in terms of therapeutic efficacy and toxicity 
Singh, et al:: Role of theophyllines and leukotriene modifiers in COPD

\begin{tabular}{|c|c|c|c|c|}
\hline $\begin{array}{l}\text { Author/ } \\
\text { year }\end{array}$ & Type of study & Demographic profile of cohort & Results & Conclusion \\
\hline $\begin{array}{l}\text { Whitfield } \\
\text { et al., } \\
1951^{[32]}\end{array}$ & $\begin{array}{l}\text { Lancet trial } \\
\text { Comparative study } \\
\text { No randomization }\end{array}$ & $\begin{array}{l}12 \text { cases of emphysema without } \\
\text { bronchospasm } \\
6 \text { healthy controls } \\
\text { Lung volumes and tidal air tracings } \\
\text { were determined before and } \\
\text { after the oral administration of } \\
\text { aminophylline in both groups }\end{array}$ & $\begin{array}{l}\text { Healthy controls: No change in the lung } \\
\text { volume or spirographic pattern } \\
\text { Emphysema: Slight } \downarrow \text { in TLV, FRC and } \\
\text { RV following administration of drug in } \\
\text { sitting position } \\
\text { No change in lung volumes in } \\
\text { recumbency position } \\
\text { Tidal-air tracings in emphysematous } \\
\text { group were unchanged }\end{array}$ & $\begin{array}{l}\text { Aminophylline, in the } \\
\text { absence of bronchospasm, } \\
\text { has no place in the treatment } \\
\text { of emphysema }\end{array}$ \\
\hline $\begin{array}{l}\text { Usery et al., } \\
2008^{[33]}\end{array}$ & $\begin{array}{l}\text { Systematic } \\
\text { literature search of } \\
\text { studies related to } \\
\text { role of leukotriene } \\
\text { modifiers in COPD } \\
(1950-2007)\end{array}$ & $\begin{array}{l}7 \text { studies identified (prospective }=2 \text {, } \\
\text { retrospective }=1 \text {, randomized } \\
\text { placebo controlled }=1 \text {, in vitro }=1 \text {, } \\
\text { double blind cross-over }=1 \text {, } \\
\text { randomized, prospective, single } \\
\text { blind, controlled }=1 \text { ) }\end{array}$ & $\begin{array}{l}\text { No conclusive evidence available for } \\
\text { benefit of leukotriene modifiers in COPD } \\
\text { Drugs may offer benefits to patients with } \\
\text { COPD, including effects that pertain } \\
\text { to airflow limitation, neutrophil and } \\
\text { lymphocyte chemotaxis, and neutrophil } \\
\text { longevity }\end{array}$ & $\begin{array}{l}\text { Reduction of symptoms, } \\
\text { improvement of objective } \\
\text { measures of disease and } \\
\text { control of inflammation } \\
\text { when added to conventional } \\
\text { treatment } \\
\text { Further studies are needed to } \\
\text { determine the precise role }\end{array}$ \\
\hline $\begin{array}{l}\text { Woodruff } \\
\text { et al., } \\
2011^{[28]}\end{array}$ & $\begin{array}{l}\text { Randomized } \\
\text { double-blind, } \\
\text { placebo controlled, } \\
\text { parallel group }\end{array}$ & $\begin{array}{l}\text { Randomization: } 60 \text { COPD patients } \\
\text { to Zileuton } 600 \mathrm{mg} \text { PO QID versus } \\
59 \text { COPD patients to placebo } \\
\text { Treatment for } 14 \text { days starting }\end{array}$ & $\begin{array}{l}\text { No difference in hospital length of stay } \\
(3.75 \pm 2.19 \text { vs. } 3.86 \pm 3.06 \text { days), } P=0.39) \\
\text { No difference in treatment failure ( } 23 \% \\
\text { vs. } 27 \%, P=0.63)\end{array}$ & $\begin{array}{l}\text { No convincing evidence } \\
\text { suggesting benefit of drug } \\
\text { in COPD due to insufficient } \\
\text { sample size }\end{array}$ \\
\hline
\end{tabular}

$\begin{array}{ll}\text { Moosavi } & \text { Interventional } \\ \text { et al., } & \text { Quasi-experimental } \\ 2013^{[34]} & \text { study }\end{array}$

Lee et al. $2015^{[26]}$ and meta-analysis
Systematic review within 12 hours of hospital admission for COPD exacerbation Primary outcome: Hospital length of stay

Secondary outcomes: Treatment failure and biomarkers of leukotriene production

25 patients with moderate-to-severe COPD in stable state

Treatment: $40 \mathrm{mg}$ oral zafirlukast daily for 2 weeks

Spirometry performed both at the baseline and at the end of the study Follow-up period: 2 weeks

7 studies involving 342 COPD patients treated with leukotriene modifiers

1578 proven COPD with at least 2 exacerbations (treated with antibiotics, oral corticosteroids, or both) in the previous year and were using an inhaled corticosteroid Randomization: 791 received low-dose theophylline (200 mg OD or BD daily) versus 787 received placebo
Significant decline in urinary LTE (4)

levels in the drug-treated group as compared to placebo at 24 and $72 \mathrm{~h}$

Mean improvements in FVC, FEV1 and FEV1/FVC were $4.75 \%$ ( $S D=13.18)$, $3.71 \%(\mathrm{SD}=9.19)$ and $9.33(\mathrm{SD}=27.08)$, respectively

Zafirlukast produced a nonsignificant $(P>0.05)$ bronchodilation, with maximum mean increase in FEV1 $0.04 \mathrm{~L}(3 \%)$ above baseline

Pooled estimation from 3 RCTs did not demonstrate any significant benefit with drugs

$\uparrow$ FEV1 (overall effect: $0.09 \mathrm{~L}, 95 \% \mathrm{CI}$ : $-0.04-0.21 ; P=0.17$; $(2)=41.0 \%)$

$\uparrow \mathrm{FVC}$ (overall effect: $0.04 \mathrm{~L}, 95 \% \mathrm{CI}$ : $-0.04-0.11 ; P=0.64$; I (2) $=0.0 \%$ )

No effect on level of myeloperoxidase (SMD, -0.15 ; 95\% CI: $-0.65-0.36$ ) or LTB4 (SMD, $-0.41 ; 95 \%$ CI: $-0.96-0.13$ ) $\downarrow$ frequency of dyspnea (RR $0.43 ; 95 \%$ CI: $0.29-0.64$ ) and sputum (RR $0.37 ; 95 \%$ CI: $0.22-0.63$ )

Data available for $1536 / 1578$ participants (98\%)

772 in theophylline group versus 764 in placebo group

Total exacerbations noted 3430

1727 in the theophylline group versus

1703 in the placebo group

Mean exacerbations per year

2.24 (95\% CI: $2.10-2.38$ ) in theophylline group versus 2.23 (95\% CI: $2.09-2.37$ ) in placebo group
Zafirlukast has no considerable bronchodilatory effect in COPD

Very short treatment period for observation of benefit

Additional larger studies are needed to verify role

Overall lack of evidence to support the therapeutic efficacy of leukotriene modifiers in patients with COPD

Further large-scale, long-term studies are needed to identify predictive factors for COPD patients who may benefit from these agents

Addition of low-dose theophylline, compared with placebo, did not reduce the number of annual COPD exacerbations

No supporting evidence the for low-dose theophylline as adjunctive therapy to inhaled corticosteroids 
Singh, et al.: Role of theophyllines and leukotriene modifiers in COPD

\begin{tabular}{|c|c|c|c|c|}
\hline $\begin{array}{l}\text { Author/ } \\
\text { year }\end{array}$ & Type of study & Demographic profile of cohort & Results & Conclusion \\
\hline $\begin{array}{l}\text { Liu et al., } \\
2018^{[35]}\end{array}$ & $\begin{array}{l}\text { Systematic review } \\
\text { and meta-analysis } \\
\text { including } \\
\text { randomized } \\
\text { controlled studies }\end{array}$ & $\begin{array}{l}\text { Six studies including } 221 \mathrm{COPD} \\
\text { patients treated with LTRA }\end{array}$ & $\begin{array}{l}\text { Pooled effect size } \\
\text { No significant improvement in FEV1 } \\
\text { (SMD: } 0.28,95 \% \text { CI: } 0.17-0.72, P=0.227 \text { ) } \\
\text { FVC (SMD: } 0.54,95 \% \text { CI: } 0.10-1.18 \text {, } \\
P=0.597 \text { ) } \\
\text { FEV1/FVC (SMD: } 0.18,95 \% \text { CI: } \\
0.09-0.46, \mathrm{P}=0.189 \text { ) } \\
\text { Subgroup analysis } \\
\text { Short-term ( }<1 \text { year) (SMD: } 0.47,95 \% \\
\text { CI: }-0.06-0.99, P=0.082) \\
\text { Long-term }(\geq 1 \text { year) (SMD: }-0.13,95 \% \\
\text { CI: }-0.57-0.31, P=0.561)\end{array}$ & $\begin{array}{l}\text { No improvement in lung } \\
\text { function of COPD patients } \\
\text { Neither short-term nor } \\
\text { long-term exposure of LTRA } \\
\text { can improve lung function } \\
\text { decline in COPD } \\
\text { Large scale randomized } \\
\text { controlled trials are urgently } \\
\text { warranted }\end{array}$ \\
\hline $\begin{array}{l}\text { Jenkins } \\
\text { et al., } \\
2019^{[36]}\end{array}$ & $\begin{array}{l}\text { TASCS } \\
\text { Multi-centric } \\
\text { Double-blind, } \\
\text { double dummy } \\
\text { placebo controlled } \\
\text { three arm } \\
\text { randomized trial }\end{array}$ & $\begin{array}{l}1670 \text { moderate-to-very severe } \\
\text { COPD patients } \\
\text { Randomization to three groups } \\
\text { a. Low-dose theophylline } 100 \mathrm{mg} \\
\text { BD + Prednisone } 5 \mathrm{mg} \text { daily } \\
\text { b. Low-dose theophylline } 100 \mathrm{mg} \\
\text { BD + Placebo } \\
\text { c. Placebo BD + placebo daily } \\
\text { Follow-up duration: } 1 \text { year }\end{array}$ & $\begin{array}{l}1211 \text { completed study } \\
43 \% \text { reported annual exacerbation } \\
\text { No difference in mean exacerbation rates } \\
\text { among three groups } 1.07(0.92-1.3) \text { versus } \\
0.95(0.81-1.11) \text { versus } 1.03(0.88-1.21)\end{array}$ & $\begin{array}{l}\text { Addition of low-dose } \\
\text { theophylline with oral } \\
\text { steroids compared with other } \\
\text { two groups, did not reduce } \\
\text { the number of exacerbations } \\
\text { over a 1-year period }\end{array}$ \\
\hline $\begin{array}{l}\text { NICE } \\
\text { COPD } \\
2018^{[37]}\end{array}$ & $\begin{array}{l}\text { Guideline for } \\
\text { COPD patients } \\
\text { with age } 16 \text { years } \\
\text { or older }\end{array}$ & \multicolumn{3}{|c|}{$\begin{array}{l}\text { Only use intravenous theophylline as an adjunct to exacerbation management if there is an inadequate respo } \\
\text { nebulized bronchodilators } \\
\text { Monitoring of drug levels recommended as there is pharmacokinetic interaction with other drugs as well as } \\
\text { associated adverse events for both oral and intravenous formulations }\end{array}$} \\
\hline $\begin{array}{l}\text { GOLD } \\
\text { COPD } \\
(2018)^{[1]}\end{array}$ & Guideline & \multicolumn{3}{|c|}{$\begin{array}{l}\text { Theophylline exerts a small bronchodilator effect in stable COPD and associated with modest symptomatic ben } \\
\text { Theophylline is not recommended unless other long term bronchodilators are unavailable or unaffordable } \\
\text { Theophyllines or methylxanthines are not indicated for the treatment of exacerbation due to increased adverse } \\
\text { events profiles } \\
\text { Leukotriene modifier has not been adequately tested in COPD patients }\end{array}$} \\
\hline
\end{tabular}

COPD: Chronic obstructive pulmonary disease; TLV: Total lung volume; RV: Residual volume; FRC: Functional residual capacity; FVC: Forced vital capacity; SD: Standard deviation; SMD: Standardized mean deviation; GOLD: Global initiative for chronic obstructive lung disease; NICE: National Institute for Health and Care Excellence; LTRA: Leukotriene receptor antagonist; TWICS: Theophylline with inhaled corticosteroids in COPD; TASCS: Theophylline and systemic corticosteroids in COPD, CI: Confidence interval

profile, followed by aminophylline and theophylline. ${ }^{[14]}$ This class of drugs is currently indicated as add-on therapy primarily in advanced COPD continuing to have symptoms despite optimum inhaled therapy including inhaled corticosteroids (ICS), long acting beta agonist (LABA), and long acting muscarinic antagonist to achieve symptomatic relief, improvement in quality of life and possible reduction in exacerbations. ${ }^{[1,15]}$ It can be used as an alternative in COPD patients noncompliant with inhalers for any reason. ${ }^{[15]}$

It has been proposed that there is the occurrence of steroid resistance even at higher doses in smokers with COPD due to neutrophilic infiltration of airways as well as sputum and also due to increase in survival life of neutrophils by inhibition of apoptosis. This could lead to impaired HDAC activity that can be restored by the addition of low-dose theophylline to ICS, showing the potential utility of drug. ${ }^{[16]}$

A single-blinded, prospective, randomized, placebo-controlled study reported reduction in dyspnea, improvement in exercise performance, and lung functions in 58 moderate-to-severe COPD patients when theophylline was added to LABA and ICS combination. ${ }^{[17]}$ However, a recent randomized control trial reported that the addition of low-dose theophylline to ICS in COPD patients having high risk of exacerbation did not reduce the annual number of exacerbations as compared to placebo. ${ }^{[18]}$ The findings do not support the use of low-dose theophylline as adjunctive therapy in the prevention of COPD exacerbations.

The existing Global Initiative for Chronic Obstructive Lung Disease (GOLD) guidelines do not recommend oral or intravenous aminophylline in patients hospitalized with COPD exacerbations due to significant adverse effects. ${ }^{[1]}$ Theophylline exerts minimal bronchodilatory effects in COPD with modest symptomatic improvement. It improved FEV1 when added to LABA, such as salmeterol compared with LABA alone. However, GOLD also does not recommend these drugs as a long-term controller for COPD unless other agents are unavailable or unaffordable. ${ }^{[1]}$ 


\section{Role of Leukotriene Modifiers in Chronic Obstructive Pulmonary Disease}

The leukotriene modifiers are another class of oral drugs that include montelukast, zafirlukast, and zileuton. ${ }^{[19]}$ All these drugs show anti-inflammatory activity by acting on different sites in 5-lipoxygenase pathway. The first two drugs are selective leukotriene receptor antagonists that selectively block the CysLT1 receptor leading to prevention of leukotriene specifically LTD4 and LTE4 from binding to the CysT1 receptor whereas the last is an inhibitor of the enzyme 5-lipo-oxygenase that is responsible for the production of leukotrienes (LTC4, LTD4, LTE4, and LTB4) which are potent bronchoconstrictors. The blockade of the leukotrienes leads to modest bronchodilation with an onset of action of 1-2 h. Zileuton has shown better improvement in FEV1 as compared to montelukast and zafirlukast because the former blocks the leukotriene pathway at the level of 5-lipoxygenase with additional effects occur on LTB4 as well as on the other leukotrienes. ${ }^{[19]}$

Clinical benefits include symptom relief, modest bronchodilation, reduction in exacerbations, and relief of allergic rhinitis symptoms. Dosing of these drugs is as follows: montelukast $10 \mathrm{mg}$ once daily; zafirlukast $20 \mathrm{mg}$ twice daily on empty stomach; and zileuton $600 \mathrm{mg} 4$ times daily or $1200 \mathrm{mg}$ twice daily for extended-release product. Potential drug interactions include zafirlukast with warfarin leading to increase in prothrombin time, decrease in levels of zafirlukast co-administered with erythromycin and increase in levels of theophylline when given concurrently with zafirlukast and zileuton. All these drugs are generally well-tolerated but may be associated with headache, dyspepsia, nausea, pharyngitis, flu-like symptoms, sleep disturbances, hallucinations, and drowsiness. Deranged liver function test was reported with zileuton. Churg-Strauss syndrome was rarely reported with leukotriene modifiers. All these drugs are indicated as an alternative therapy for mild asthma and also as an add-on agents given in combination with other therapies such as ICS/ LABA for moderate-to-severe asthma. ${ }^{[19,20]}$

Montelukast is also indicated for the acute prevention of exercise-induced bronchoconstriction as well as for the treatment of aspirin-induced asthma and allergic rhinitis. ${ }^{[20]}$ However, there is no current indication for using leukotriene modifiers in COPD as evidence is limited. These classes of drugs might show a promising role in patients of COPD. Studies have reported higher levels of LTB4 in the sputum of COPD patients than in controls and also overexpression of CysLT1 receptors in the bronchial mucosa of COPD patients having frequent exacerbations than in normal individuals or stable COPD. ${ }^{[21-23]}$ In a subset of COPD patients with exacerbations, increased infiltration of bronchial mucosa with eosinophils has been observed, and montelukast with or without ICS might be effective in reducing the number of eosinophils. ${ }^{[8,19,21]}$ A small retrospective series comprising 20 moderate-to-severe elderly COPD patients treated with montelukast on long-term basis reported modest benefit with reduced symptoms, emergency department visits, required doses of ICS but no change in lung function as compared to that group treated without montelukast. ${ }^{[24]}$

Another study used montelukast on a short-term basis in moderate-to-severe COPD patients and reported that the addition of this drug to routine treatment protocol produced additional improvement on lung function, dyspnea score, and quality of life in patients with stable COPD suggesting need for an additional anti-inflammatory treatment. ${ }^{[25]}$ A systematic review and meta-analysis in 2015 reviewed leukotriene inhibitor therapy for COPD and observed that there was a modest improvement in lung function and symptom scores and found no improvement in lung function and no reduction of myeloperoxidase/neutrophilic inflammation markers or LTB4. ${ }^{[26]}$ A study reported that leukotriene synthesis inhibitor did not benefit COPD patients, although there was a modest reduction in neutrophilic inflammation with a 14-day therapy ${ }^{[27]}$ There is a lack of evidence to support the therapeutic efficacy of anti-leukotriene agents in COPD but more number of studies, including well-designed randomized controlled trials with larger sample size, are required.

A larger study reported that the addition of zileuton to routine care had no impact on treatment outcomes in patients hospitalized with exacerbations of COPD.$^{[28]}$ Patients with characteristics of both COPD and asthma sometimes referred to as asthma COPD overlap (ACO), may be more likely to benefit from montelukast therapy. A retrospective study of inner city veterans with COPD reported that 2 years of montelukast therapy is associated with decreased emergency department and urgent care utilization for exacerbations (from 34 to 22, $35 \%: P=0.03){ }^{[29]}$ One well-designed trial in 39 smoking asthmatics likely representing ACO subgroup suggested that a better response to montelukast was observed as compared to ICS as compared to nonsmoking asthmatics. ${ }^{[30]}$ Leukotriene modifiers have been prescribed frequently in patients of COPD in view of presumed diagnosis of ACO ${ }^{[31]}$ More studies are required to prove definite role of leukotriene modifiers in ACO.

\section{ConcLusion}

Whether theophyllines and leukotriene modifiers are still to be considered for treatment or to be withdrawn remains inconclusive. The existing review of literature supporting their roles remain weak, as shown in Table $1 .^{[1,18,26,28,32-37]}$ Despite the controversy about the exact role of these drugs whether used alone or in combination, they remain the most commonly used drugs worldwide on a traditional basis due to cost-effectiveness, availability, and ease of administration as compared to inhaled therapies. Studies have reported that most of the prescriptions by general practitioners are not always in accordance with GOLD guidelines. These two groups of drugs have been prescribed frequently either alone or along with inhaled therapies in multiple irrational combinations among COPD patients at various tertiary care centers leading 


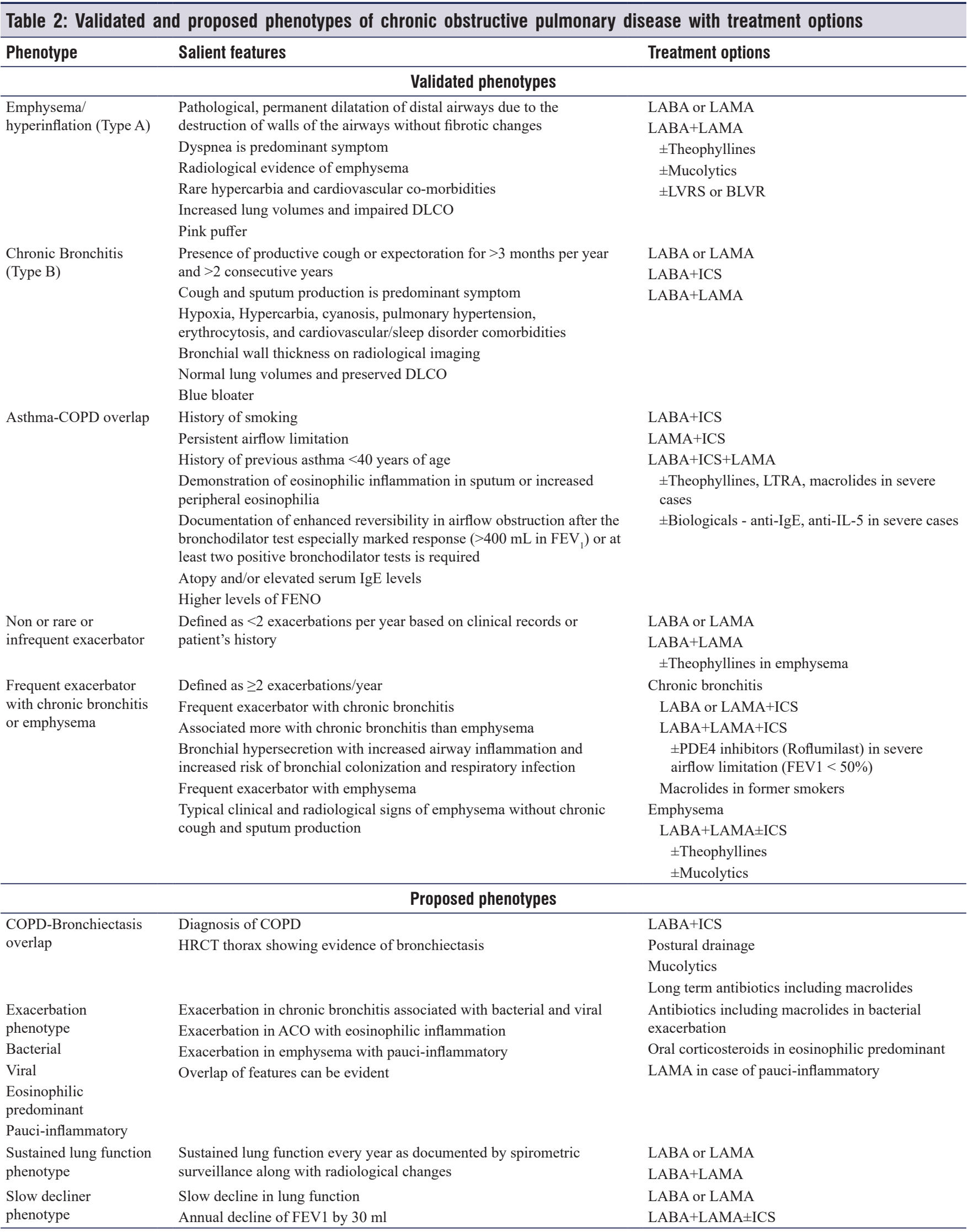


Singh, et al:: Role of theophyllines and leukotriene modifiers in COPD

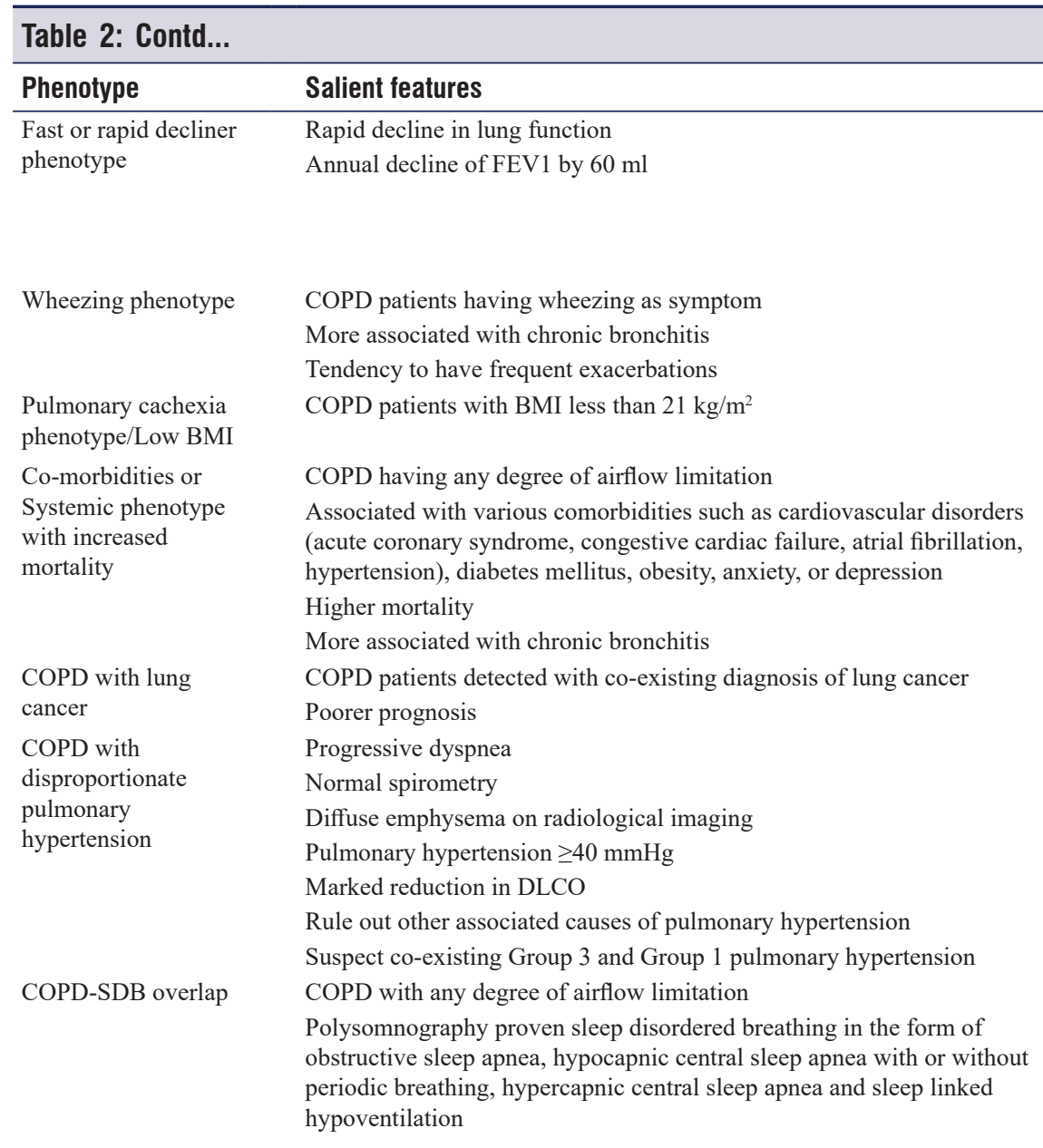

\section{Treatment options}

LABA+LAMA
LABA+LAMA+ICS

Aggressive disease management including LVRS and pulmonary rehabilitation

Referral for Lung transplantation

Treatment similar for chronic bronchitis phenotype

Nutritional supplementation Pulmonary rehabilitation

Aggressive management of co-morbidities Psychosocial support/behavioural therapy in case of anxiety or depression

Treatment of lung cancer

Long-term oxygen therapy

Diuretics, anticoagulation

Pulmonary vasodilators either single or dual can be used

Lung transplantation

Treatment of sleep disordered breathing with appropriate PAP devices

OSA- CPAP

Hypocapnic CSA with LVEF $\leq 45 \%$ - CPAP, oxygen therapy, acetazolamide, positional therapy Hypocapnic CSA with LVEF $>45 \%$ - ASV OSA requiring higher pressures of CPAP, Hypoventilation - BIPAP Hypercapnic CSA, hypoventilation - BIPAP S/T

Bullectomy in case of bullae

Either LVRS or BLVR (valve, coil, vapor ablation) in heterogeneous or homogeneous emphysema Valve not indicated in case of collateral ventilation Lung transplantation in those cases not candidates for LVRS, BLVR, and bullectomy

Alpha 1 antitrypsin augmentation therapy

Early onset emphysema

Unopposed effects of neutrophil elastase and other serine proteases

Mutation of the telomerase gene TERT creating short telomeres

-leading to cellular senescence

Early onset emphysema

Female predominant

Increased risk of pneumothorax

Persistent inflammatory Presence of persistent systemic inflammation by measuring biomarkers phenotype such as WBC, CRP, IL-6, IL-8, fibrinogen, and TNF- $\alpha$

Predominant small airway disease with little emphysema
Treatment similar to chronic bronchitis phenotype

Treatment similar to chronic bronchitis phenotype

Biomass fuel exposure/

Outdoor or indoor air

pollution

ACO: Asthma-COPD overlap, ASV: Adaptive servo-ventilation, BIPAP: Bi-level positive airway pressure, BIPAP ST: Bi-level positive airway pressure Spontaneous/Timed, BLVR: Bronchoscopic lung volume reduction, BMI: Body mass index, COPD: Chronic obstructive pulmonary disease, CPAP: Continuous positive airway pressure, CRP: C-reactive protein, CSA: Central sleep apnea, DLCO: Diffusion lung capacity for carbon monoxide, FENO: Fractional exhalation of nitric oxide, FEV1: Forced expiratory volume in one second, ICS: Inhaled corticosteroids, IL-Interleukin, LABA: Long acting beta2 agonist, LAMA: Long acting muscarinic antagonist, LTRA: Leukotriene receptor antagonist, LVEF: Left ventricular ejection fraction, LVRS: Lung volume reduction surgery, OSA-Obstructive sleep apnea, PAP: Positive airway pressure, PDE4: Phosphodiesterase 4, SDB: Sleep disordered breathing, TNF alpha: Tumor necrosis factor alpha, WBC: White blood cell 
to increased incidence of adverse drug reactions (ADRs). ${ }^{[38-40]}$ Polypharmacy has been associated with multiple ADRs with few of them overlapping or being additive as one or more class of drugs can be responsible. The use of oral theophylline in particular requires cautious therapeutic monitoring and dose individualization. ${ }^{[41]}$ There is a requirement of increased awareness among physicians regarding the rational use of these drugs among patients with COPD. In summary, there is no compelling evidence of benefit of theophyllines and leukotriene modifiers in the treatment of COPD. Their role needs to be justified by strong evidence.

\section{Phenotyping of Chronic Obstructive Pulmonary Disease: Future Prospects}

COPD has now been considered to be a heterogeneous disease, such as asthma and lung cancer. The concept of heterogeneity arises from the fact that COPD patients manifest with diverse clinical features (symptoms, comorbidities, and frequency of exacerbation) for a similar degree of airflow limitation based on FEV1. The concept of universal therapy for all seems to be outdated and personalized therapy is required. Several phenotypes have been proposed based on expanding evidence over the last decade. ${ }^{[42-45]}$ However, only few of them have been validated as described in Table 2. Categorization of all COPD patients into a particular phenotype seems to be practically difficult as many of them will have overlapping clinical manifestations and comorbidities. The phenotyping approach to COPD based on various parameters related to three domains (severity, activity, and impact) will potentiate targeted therapy that can guide clinicians to prescribe appropriate drugs. This approach will promote precision medicine in COPD leading to change in clinical practice but larger trials are required for validation in the near future.

\section{Financial support and sponsorship}

Nil.

\section{Conflicts of interest}

There are no conflicts of interest.

\section{REFERENCES}

1. Global Strategy for the Diagnosis, Management and Prevention of COPD. Global Initiative for Chronic Obstructive Lung Disease (GOLD). Global Strategy for the Diagnosis, Management and Prevention of COPD; 2018. Available from: http://goldcopd.org. [Last accessed on 2019 Aug 28].

2. Adeloye D, Chua S, Lee C, Basquill C, Papana A, Theodoratou E, et al. Global and regional estimates of COPD prevalence: Systematic review and meta-analysis. J Glob Health 2015;5:020415.

3. Lozano R, Naghavi M, Foreman K, Lim S, Shibuya K, Aboyans V, et al. Global and regional mortality from 235 causes of death for 20 age groups in 1990 and 2010: A systematic analysis for the Global Burden of Disease Study 2010. Lancet 2012;380:2095-128.

4. GBD 2013 Mortality and Causes of Death Collaborators. Global, regional, and national age-sex specific all-cause and cause-specific mortality for 240 causes of death, 1990-2013: A systematic analysis for the Global Burden of Disease Study 2013. Lancet 2015;385:117-71.

5. Vos T, Flaxman AD, Naghavi M, Lozano R, Michaud C, Ezzati M, et al. Years lived with disability (YLDs) for 1160 sequelae of 289 diseases and injuries 1990-2010: A systematic analysis for the Global Burden of Disease Study 2010. Lancet 2012;380:2163-96.

6. Jindal SK, Aggarwal AN, Gupta D, Agarwal R, Kumar R, Kaur T, et al. Indian study on epidemiology of asthma, respiratory symptoms and chronic bronchitis in adults (INSEARCH). Int J Tuberc Lung Dis 2012;16:1270-7.

7. Salvi S, Agrawal A. India needs a national COPD prevention and control programme. J Assoc Physicians India 2012;60 Suppl:5-7.

8. Pleasants RA. Clinical pharmacology of oral maintenance therapies for obstructive lung diseases. Respir Care 2018;63:671-89.

9. Barnes PJ. Theophylline: New perspectives for an old drug. Am J Respir Crit Care Med 2003;167:813-8.

10. Ito $\mathrm{K}$, Lim S, Caramori G, Cosio B, Chung KF, Adcock IM, et al. A molecular mechanism of action of theophylline: Induction of histone deacetylase activity to decrease inflammatory gene expression. Proc Natl Acad Sci U S A 2002;99:8921-6.

11. Ram FS, Jardin JR, Atallah A, Castro AA, Mazzini R, Goldstein R, et al. Efficacy of theophylline in people with stable chronic obstructive pulmonary disease: A systematic review and meta-analysis. Respir Med 2005;99:135-44.

12. Barnes PJ. Theophylline. Pharmaceuticals (Basel) 2010;3:725-47.

13. Chrystyn H, Mulley BA, Peake MD. Dose response relation to oral theophylline in severe chronic obstructive airways disease. BMJ 1988;297:1506-10.

14. Cazzola M, Calzetta L, Barnes PJ, Criner GJ, Martinez FJ, Papi A, et al. Efficacy and safety profile of xanthines in COPD: A network meta-analysis. Eur Respir Rev 2018;27. pii: 180010.

15. Gupta D, Agarwal R, Aggarwal AN, Maturu VN, Dhooria S, Prasad KT, et al. Guidelines for diagnosis and management of chronic obstructive pulmonary disease: Joint ICS/NCCP (I) recommendations. Lung India 2013;30:228-67.

16. Barnes PJ. Corticosteroid resistance in patients with asthma and chronic obstructive pulmonary disease. J Allergy Clin Immunol 2013;131:636-45.

17. Subramanian, Ragulan, Jindal A, Viswambhar V, Arun Babu VM. The study of efficacy, tolerability and safety of theophylline given along with formoterol plus budesonide in COPD. J Clin Diagn Res 2015;9:OC10-3.

18. Devereux G, Cotton S, Fielding S, McMeekin N, Barnes PJ, Briggs A, et al. Effect of theophylline as adjunct to inhaled corticosteroids on exacerbations in patients with COPD: A randomized clinical trial. JAMA 2018;320:1548-59.

19. Montuschi P. Role of leukotrienes and leukotriene modifiers in asthma. Pharmaceuticals (Basel) 2010;3:1792-811.

20. Global Initiative for Asthma. Global Strategy for Asthma Management and Prevention. Global Initiative for Asthma; 2019. Available from: http://ginasthma.org. [Last accessed on 2019 Aug 29].

21. Scott JP, Peters-Golden M. Anti-leukotriene agents for the treatment of lung disease. Am J Respir Crit Care Med 2013;188:538-44.

22. Profita M, Giorgi RD, Sala A, Bonanno A, Riccobono L, Mirabella F, et al. Muscarinic receptors, leukotriene B4 production and neutrophilic inflammation in COPD patients. Allergy 2005;60:1361-9.

23. Zhu J, Bandi V, Qiu S, Figueroa DJ, Evans JF, Barnes N, et al. Cysteinyl leukotriene 1 receptor expression associated with bronchial inflammation in severe exacerbations of COPD. Chest 2012;142:347-57.

24. Rubinstein I, Kumar B, Schriever C. Long-term montelukast therapy in moderate to severe COPD - a preliminary observation. Respir Med 2004;98:134-8.

25. Celik P, Sakar A, Havlucu Y, Yuksel H, Turkdogan P, Yorgancioglu A. Short-term effects of montelukast in stable patients with moderate to severe COPD. Respir Med 2005;99:444-50.

26. Lee JH, Kim HJ, Kim YH. The effectiveness of anti-leukotriene agents in patients with COPD: A systemic review and meta-analysis. Lung 2015;193:477-86.

27. Gompertz S, Stockley RA. A randomized, placebo-controlled trial of a leukotriene synthesis inhibitor in patients with COPD. Chest 2002;122:289-94.

28. WoodruffPG,AlbertRK, Bailey WC, CasaburiR, ConnettJE, CooperJAJr, et al. Randomized trial of zileuton for treatment of COPD exacerbations requiring hospitalization. COPD 2011;8:21-9.

29. Rubinstein I, Whitten B, Heneghan M, Ng J. Visits to emergency 
department and urgent care facility by Inner-city Chicago Veterans with asthma-COPD overlap who are treated with montelukast for 2 years. Am J Respir Crit Care Med 2018;197:A1360.

30. Lazarus SC, Chinchilli VM, Rollings NJ, Boushey HA, Cherniack R, Craig TJ, et al. Smoking affects response to inhaled corticosteroids or leukotriene receptor antagonists in asthma. Am J Respir Crit Care Med 2007; 175:783-90.

31. Ding B, Small M. Treatment trends in patients with asthma-COPD overlap syndrome in a COPD cohort: Findings from a real-world survey. Int J Chron Obstruct Pulmon Dis 2017;12:1753-63.

32. Whitfield AG, Arnott WM, Waterhouse JA. Effect of aminophylline in emphysema. Lancet 1951;1:490-2.

33. Usery JB, Self TH, Muthiah, MP, Finch CK. Potential role of leukotriene modifiers in the treatment of chronic obstructive pulmonary disease. Pharmacotherapy 2008;28:1183-7.

34. Moosavi SA, Raji H, Tasorian B, Mostafapour E, Shahabi S, Purfakharan M, et al. Effect of Zafirlukast on improving lung function in patients with chronic obstructive pulmonary diseases. Med J Islam Repub Iran 2013;27:57-61.

35. Liu L, Wang JL, Xu XY, Feng M, Hou Y, Chen L. Leukotriene receptor antagonists do not improve lung function decline in COPD: A meta-analysis. Eur Rev Med Pharmacol Sci 2018;22:829-34.

36. Jenkins CR, Wen FQ, Barnes PJ, Celli BR, Zhong NS, Zheng JP, et al. Theophylline and systemic corticosteroids in COPD: The TASCS trial. AJRCCM 2019;199:A7444.

37. NICE Guideline. Chronic Obstructive Pulmonary Disease in Over 16s:
Diagnosis and Management; 05 December, 2018. Available from: http:// www.nice.org.uk/guidance/ng115. [Last accessed on 2019 Oct 10].

38. Corrado A, Rossi A. How far is real life from COPD therapy guidelines? An Italian observational study. Respir Med 2012;106:989-97.

39. Fitch K, Iwasaki K, Pyenson B, Plauschinat C, Zhang J. Variation in adherence with Global Initiative for Chronic Obstructive Lung Disease (GOLD) drug therapy guidelines: A retrospective actuarial claims data analysis. Curr Med Res Opin 2011;27:1425-9.

40. Maqusood M, Khan FA, Kumar M. A Study of prescription pattern in the management of COPD in a tertiary care hospital. Ann Int Med Den Res 2016;2:159-63.

41. Tyagi N, Gulati K, Vijayan VK, Ray A. A study to monitor adverse drug reactions in patients of chronic obstructive pulmonary disease: Focus on theophylline. Indian J Chest Dis Allied Sci 2008;50:199-202.

42. Burgel PR, Paillasseur JL, Caillaud D, Tillie-Leblond I, Chanez P, Escamilla R, et al. Clinical COPD phenotypes: A novel approach using principal component and cluster analyses. Eur Respir J 2010;36:531-9.

43. Miravitlles M, Soler-Cataluña JJ, Calle M, Soriano JB. Treatment of COPD by clinical phenotypes: Putting old evidence into clinical practice. Eur Respir J 2013;41:1252-6.

44. Agusti A, Edwards LD, Celli B, Macnee W, Calverley PM, Müllerova H, et al. Characteristics, stability and outcomes of the 2011 GOLD COPD groups in the ECLIPSE cohort. Eur Respir J 2013;42:636-46.

45. Han MK, Kazerooni EA, Lynch DA, Liu LX, Murray S, Curtis JL, et al. Chronic obstructive pulmonary disease exacerbations in the COPDGene study: Associated radiologic phenotypes. Radiology 2011;261:274-82. 